\title{
Biomethane Emissions: Measurement in Wastewater Pond at Palm Oil Mill by Using TGS2611 Methane Gas Sensor
}

\author{
Ledis Heru Saryono Putro ${ }^{1,2^{*}}$, Dedik Budianta ${ }^{3}$, Dedi Rohendi ${ }^{4}$, Amin Rejo ${ }^{5}$ \\ 1 Study Program of Environmental Science, Sriwijaya University, South Sumatera, Indonesia \\ 2 Department of Biology, Faculty of Science and Technology, State Islamic University of Raden Fatah Palembang, \\ South Sumatera, Indonesia \\ 3 Department of Soil Science, Faculty of Agriculture, Sriwijaya University, South Sumatera, Indonesia \\ 4 Department of Chemistry, Faculty of Mathematics and Natural Science, Sriwijaya University, South Sumatera, \\ Indonesia \\ 5 Department of Agricultural Technology, Faculty of Agriculture, Sriwijaya University, South Sumatera, \\ Indonesia \\ * Corresponding author's e-mail: Iherusp@radenfatah.ac.id
}

\begin{abstract}
Palm oil mill effluent (POME) contains high amounts of organic matter, potentially as a source of environmental pollution. The processing of POME in anaerobic ponds is produced by biomethane, which is a greenhouse gas and also is a potential as a renewable energy source. Indonesia is the world's largest CPO producer, but POME processing is still mostly done by conventional methods without methane capture. In this system, the value of methane emitted into the atmosphere is unknown. This research focused on estimating the methane emissions in anaerobic ponds (AP) multiple feeding wastewater treatment plants (WWTPs) for land applications, with $\mathrm{CH}_{4}$-meter systems based on TGS2611 sensors, SHT11 and microcontrollers, and using closed static chambers. The sampling of wastewater and methane gas was carried out in October-November 2018. The results showed that the methane gas emissions in combined anaerobic ponds (AP2-AP1) and AP3 were 43,704 and 35,321 mg/m²/day respectively, and a total of 405.358 and $61.812 \mathrm{~kg} /$ day sequential on AP2-AP1 $\left(9,275 \mathrm{~m}^{2}\right)$ and AP3 $\left(1,750 \mathrm{~m}^{2}\right)$. It was obtained from the correlation between methane emissions with removed COD as a conversion coefficient of $0.2107 \mathrm{~kg} \mathrm{CH}_{4} / \mathrm{kg}$ COD removed. On the basis of linear regression with $\mathrm{R}^{2} 0.9725$, it was still below the theoretical value (stoichiometry) of $0.25 \mathrm{~kg} \mathrm{CH}_{4} / \mathrm{kg}$ COD removed. From the conversion coefficient, COD removed, and the amount of POME in 2018 , which was $104,179 \mathrm{~m}^{3}$, contributed to emitting 462 tons of methane from the entire anaerobic pond. This conversion coefficient can be used to quickly estimate the methane emissions in Indonesian palm oil mills.
\end{abstract}

Keywords: methane emissions, $\mathrm{CH}_{4}$-meter, TGS2611 and SHT11 sensor, anaerobic pond, POME, conversion coefficient

\section{INTRODUCTION}

Indonesia is the largest palm oil producer in the world since 2006 (Djamhur, 2015). In 2016 the Indonesia's production of Crude Palm Oil (CPO) reached 33.23 million tons (Directorate General of Plantation, 2016), around $57 \%$ of world production amounted to 58.29 million tons. Indonesia is the largest exporter of palm oil, in 2016, 25.1 million tons were exported (GAPKI, 2017), with foreign exchange values reaching USD 17.8 billion and 5.9 million workers (11\%).
According to Wicke et al. (2008), in the process of processing fresh fruit bunches (FFB) of palm oil into crude palm oil (CPO), around 21.523 percent corresponded to $\mathrm{CPO}$ production; around $230 \mathrm{~kg}$ of CPO and $55 \mathrm{~kg}$ of palm kernel (PK); (Buana et al., 2004), the remainder includes by-products or solid, liquid, and gas waste. Solid waste consists of empty fruit bunches (16-23\%), fruit juice (11-26\%), palm kernel (4\%), shells (4-6\%), and other solid wastes (16.5\%). According to Mahajoeno (2008), each ton of processed fresh fruit bunches (FFB), produced $0.7 \mathrm{~m}^{3}$ of 
wastewater. According to Yuliasari et al. (2001), Morad et al. (2008), palm oil mill effluent would produce $0.75-0.90 \mathrm{~m}^{3} /$ ton $\mathrm{FFB}$ or 3.33 tons of POME (2.5-3 tons according to $\mathrm{Wu}$ et al., 2010) for every ton of CPO.

POME contains high BOD, COD, TSS, oil and grease, TS and VS, so it has the potential to be a pollutant source. Disposal of POME without treatment into the waters can pollute aquatic environment, reducing dissolved oxygen levels, deteriorating fish health and aquatic biota (Lam and Lee, 2011). The study conducted by Mahajoeno (2008) showed that POME was colloidal, thick, brown or grayish, $\mathrm{pH} 4.4-5.4$ and had an average COD content of 49.0-63.6; BOD 23.5-29.3; TS 26.5-45.4 and SS 17.1-35.9 g/L, all variables exceeded the quality standard according to the Regulation of The Environment Minister 05/2014, so it had the potential to pollute the environment.

The processing of POME in Indonesia is generally carried out relatively simply, namely by flowing and decomposition in the ponding system; there are still a few who carry out methane capture to utilize biogas for energy. In this system, POME is degraded anaerobically, which causes methane emissions. Methane emissions contribute to global warming because it is a greenhouse gas (GHG) which is 20-30 times stronger than carbon dioxide (Porteous, 1998).

One of the palm oil mill wastewater treatment systems is a multiple feeding system, where the POME output from the deoiling pond and coolant is fed simultaneously to anaerobic ponds. This system is generally applied to palm oil mills that carry out land application to plantation land. The advantages of this system are reducing the organic content and increasing the $\mathrm{pH}$ faster, shortening waste treatment, having less number of waste ponds and WWTP land area, but having treated wastewater with BOD $>1000 \mathrm{mg} / \mathrm{L}$. This WWTP system is not well-known and few researchers have reported the value of its methane emissions.

The measurement of biogas flow rate emission with the main content of biomethane, as well as other gas compositions, is still limited due to the requirements in equipment, the level of difficulty in gas sampling; the analysis costs are relatively expensive, also due to the changing nature of gas according to circumstances and environmental factors. Thus, a practical, fast and accurate measuring system is needed. Methane testing that is commonly carried out with Gas Chromatography and conducted in a laboratory was a costly method. Gas measurement methods have been developed for quantification and monitoring of greenhouse gas emissions, especially methane and carbon dioxide, in waters and installation of wastewater treatment plants, namely through closed static chambers (Yacob et al., 2005; Yacob et al., 2006; Hasanudin et al., 2006; Park and Craggs, 2007; Silva et al., 2015; Paredes et al., 2015; Lorke et al., 2015; Silva, 2016). The method being developed is a sensor-based $\mathrm{CH}_{4}{ }^{-}$ meter and microcontroller that allows continuous real-time measurement, and automatic recording (Sugriwan and Soesanto, 2017; Sugriwan et al., 2015; Eugster and Kling, 2012). This research aimed at assessing the characteristics of wastewater and estimating methane emissions in WWTP with a multiple feeding system, using the $\mathrm{CH}_{4}^{-}$ meter system based on TGS611 sensors, SHT11 sensors and microcontrollers, and the relationship of methane emissions to the levels of organic matter in POME.

\section{MATERIAL AND METHODS}

\section{Description of processing palm oil mill wastewater}

Field measurements of methane emissions and palm oil mill wastewater were conducted in Banyuasin Regency of South Sumatra Province, with a production capacity of 60 tons of FFB/ hour, within $\pm 21 \mathrm{~km}$ from Palembang (-2.826S, 104.732E). The WWTP facility consists of 7 ponds, including 3 oil quotation ponds, 1 cooling pond, and 3 anaerobic ponds (Figure 1). This research focused on anaerobic ponds with anaerobic microbial activity, characterized by the presence of active bubbles of biogas (methane) production. Three anaerobic ponds (AP) were measured in terms of methane emissions. The AP dimensions can be seen in Figure 1 with a depth of \pm 6 meters, and the total volume of all APs was $\pm 46,305 \mathrm{~m}^{3}$, with HRT $>130$ days.

Following the process, the wastewater is used oil palm plantation land, located about $1 \mathrm{~km}$ from the WWTP outlet. The wastewater treatment process starts from the deoiling pond and the cooling pond; then it is pumped and fed to AP2 and AP3 ( \pm 500 meters) together (multiple feeding), with a ratio of 50:50, 40:60, and 60:40 according to the quality of processing results to meet the $\mathrm{BOD} \leq 5000 \mathrm{mg} / \mathrm{L}$ required by POME for land 
applications. WWTP outlets on AP3 with rotary system pumps are applied to land as much as $300-$ $500 \mathrm{~m}^{3} /$ day.

\section{Monitoring the characteristics of wastewater}

Sampling of WWTP wastewater, from various types of inlet and outlet waste ponds, was carried out over two weeks period for \pm 2 months $(\mathrm{n}=6)$ includes 6 sampling locations (Figure 1). The wastewater samples, from each wastewater sampling point, were combined from the POM operations in the morning $( \pm 09.00)$ and evening $( \pm 16.00)$. In addition to composite time, pond depth composites ( $0-2$ meters) and composite locations (locations 1 and 2 in the area around the inlet or outlet of the waste pond) were also carried out. The test variables of the characteristics of wastewater included BOD, TSS, TS, VS, oil and grease with the Standard Methods for the Examination of Water and Wastewater testing method (APHA, 1998); COD using the COD-Vario Photometer-System, Lovibond; N-total with TOC/ TN Analyzer, Torch, Teledyne Tekmar. In turn, the $\mathrm{pH}$, Eh and temperature were taken directly in the field with Adwa AD-111 portable $\mathrm{pH}$ meter.

\section{Estimated methane emissions in anaerobic ponds}

Closed static chambers for biogas (methane) capture are made of transparent polypropylene (PP) material, in the form of a cylinder with the dimensions of $0.30 \times 0.28 \times 0.415 \mathrm{~m}$ (upper diameter $\times$ lower diameter $\times$ height), containment volume $=0.02742 \mathrm{~m}^{3}$ (27.42 liters) and with the wide-scale area of $0.07 \mathrm{~m}^{2}$. The chamber volume was 25.44 liters when applied above the anaerobic pond, with $3 \mathrm{~cm}$ submerged below the surface of the pond (effective height of chamber $=0.385$ $\mathrm{m}$ ); (see Figure 2) and the placement of chambers could be seen in Figure 3.

The methane (biogas) concentration measuring instrument uses a sensor system, namely $\mathrm{CH}_{4}$-meter modified from Sugriwan et al. (2015), Sugriwan and Soesanto (2017), consisting of the TGS2611 methane gas sensor, SHT11 air temperature and humidity sensor, Arduino Mega 2560 microcontroller (ATMega2560), 20x4 LCD, and data logger (micro SD) storage. The TGS2611 and SHT11 sensors from the $\mathrm{CH}_{4}$-meter were mounted on the chambers. The $\mathrm{CH}_{4}$-meter system is used to allow continuous, real-time, and automatic recording. The $\mathrm{CH}_{4}$-meter calibration of standard methane gas at 100 to $10,000 \mathrm{ppm}$, has met the precision criteria of \% RSD (relative standard deviation) and \% RSD-Horwitz (Harmita, 2004).

Chambers were positioned at three locations, each in the inlet, center and outlet of the anaerobic pond (AP2-AP1 and AP3); (Figure 3). The measurements of methane production were carried out for three days $(n=3)$ in the combined AP2-AP1 and AP3, 11 hours per day (07:00 to 18:00), with blasting of chambers every 2 hours. The reading of the concentration of methane gas with $\mathrm{CH}_{4}$-meter was carried out continuously per 2 hours. Further data processing and analysis at intervals of each data were taken per 5 minutes (12 data per hour). In order to detect the effect of

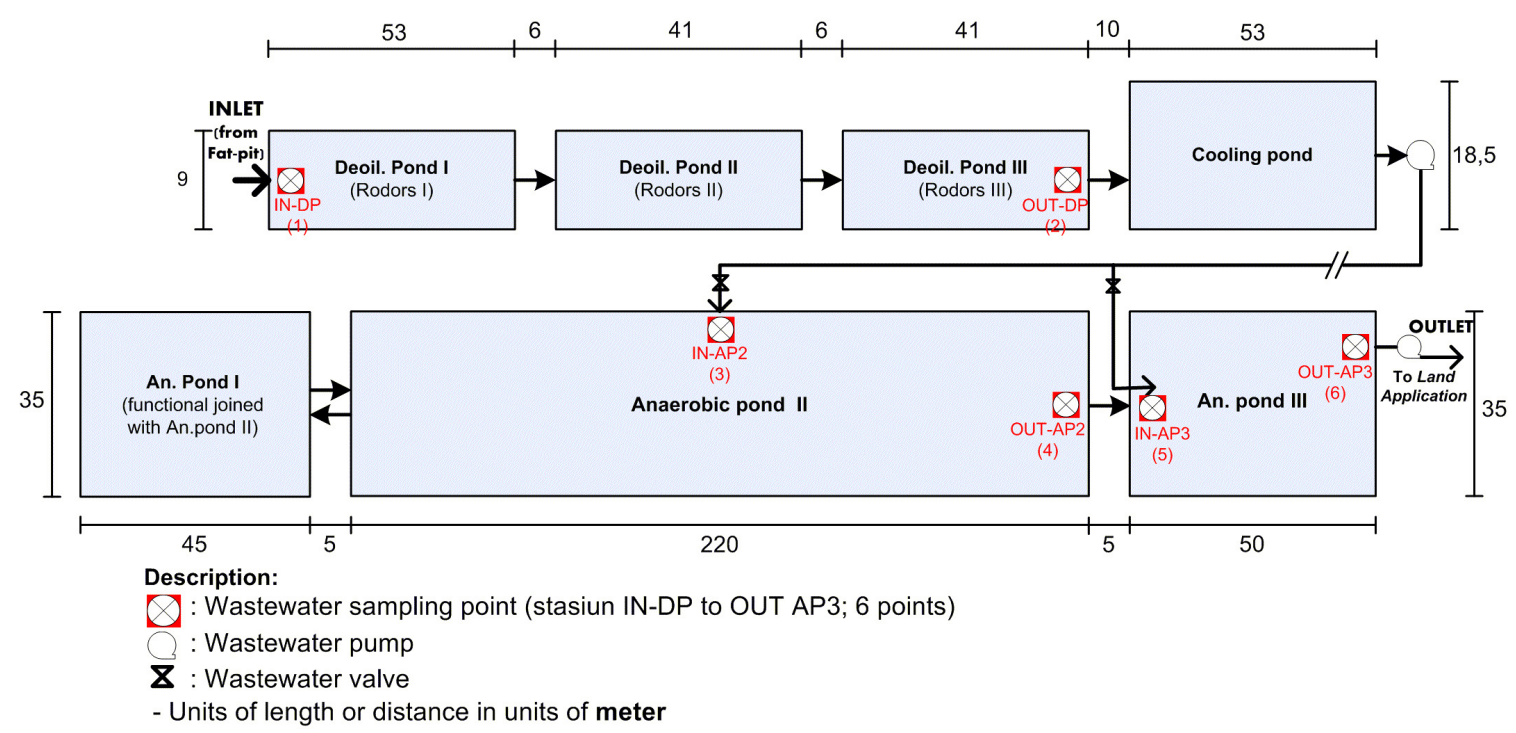

Figure 1. Plan of WWTP and location of wastewater sampling point 


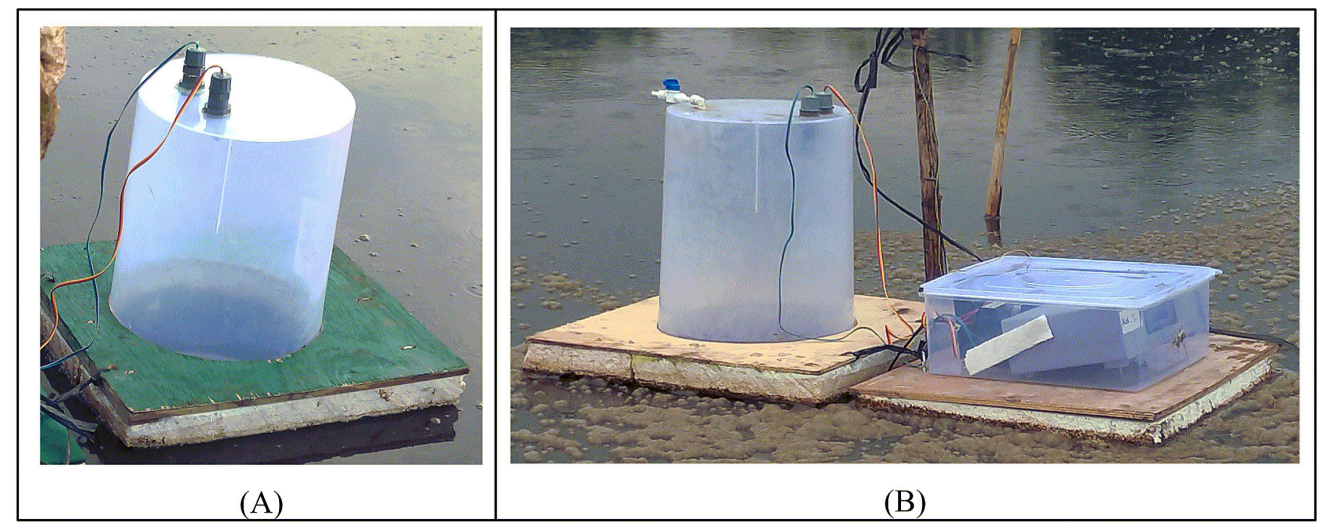

Figure 2. (A) Chamber for methane capture, (B). $\mathrm{CH}_{4}$-meter system and chamber

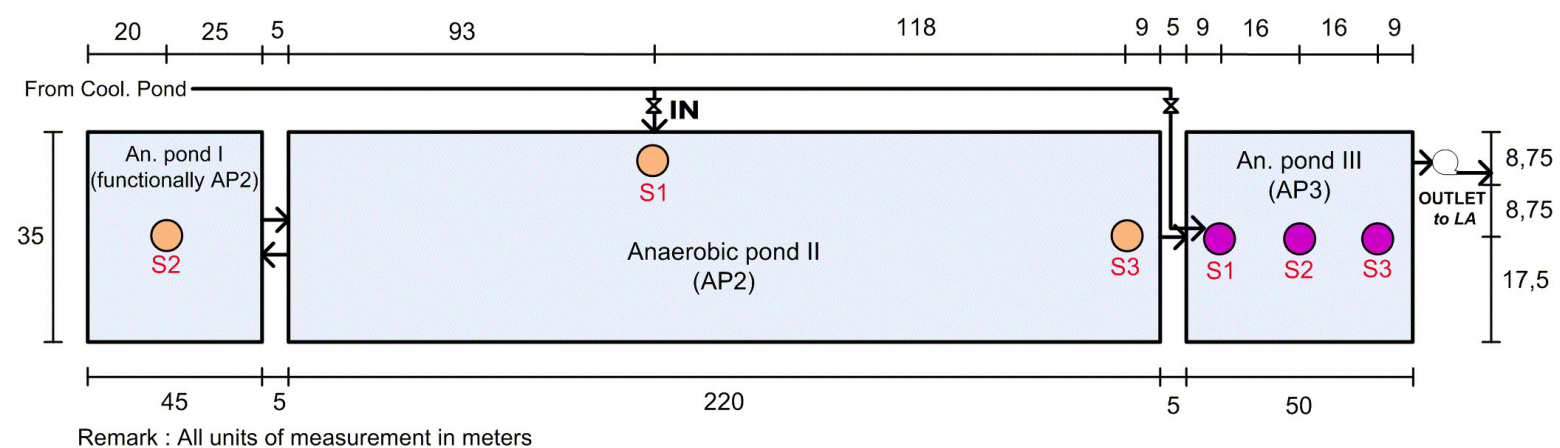

Figure 3. Placement of chambers in anaerobic ponds

rain on methane emissions, the rainfall data was used in $\mathrm{mm} / 12$ hours format. The data from raindrop station involved one group of oil palm plantation companies, within $\pm 2,000$ meters from the the WWTP outlet (-2.821S, 104.700E).

Methane emissions/fluxes were calculated as Khalil et al., 1991; IAEA, 1992; Lantin et al., 1995:

$$
E=\frac{d c}{d t} \cdot \frac{V c h}{A c h} \cdot \frac{W m}{V m} \cdot \frac{273.2}{273.2+T}
$$

where: $E$ is emission/flux $\mathrm{CH}_{4}\left(\mathrm{mg} / \mathrm{m}^{2} /\right.$ minute); $d c / d t$ is difference in $\mathrm{CH}_{4}$ concentration per unit time ( $\mathrm{ppm} /$ minute);

$V$ ch is containment volume $\left(\mathrm{m}^{3}\right)$;

Ach is cover area $\left(\mathrm{m}^{2}\right)$;

$W m$ is molecular weight $\mathrm{CH}_{4}\left(16.04 \times 10^{3}\right.$ $\mathrm{mg}$ );

$\mathrm{Vm}$ is the molecular volume of $\mathrm{CH}_{4}$ $\left(22.41 \times 10^{-3} \mathrm{~m}^{3}\right)$ and

$T$ is chamber air temperature on average at sampling $\left({ }^{\circ} \mathrm{C}\right)$.

The total rate of methane emissions per sampling point per day was calculated by integrating the emission values using the SimpsonNumericalMethod (Arif et al., 2015):

$$
\int_{a}^{b} f(x) d x \approx \frac{b-a}{6}\left[f(a)+4 f\left(\frac{a+b}{2}\right)+f(b)\right]
$$

where: $f(x)$ is total methane emissions $\left(\mathrm{mg} / \mathrm{m}^{2} /\right.$ day); $a$ is the initial hours of measurement of emissions and

$b$ is the final hour of measurement of emissions.

On the basis of the average emission rate per sampling point, the total methane emissions per day ( $\mathrm{mg} \mathrm{CH}_{4} /$ pond/day) werecalculated with the following formula:

Total emissions $\mathrm{CH}_{4}=$ average $\mathrm{CH}_{4}$ emission rate $\left(\mathrm{mg} / \mathrm{m}^{2} /\right.$ day $) \times$ anaerobic pond area $\left(\mathrm{m}^{2}\right)$

Statistical analysis was performed using IBM SPSS statistics version 25 to test the relationship between environmental variables and wastewater with methane emissions. All data from the field were tested for linearity and normal distribution. Multiple linear regression equation to achieve BLUE (best linear unbiased estimation) was carried out with regression assumption tests, namely: residual normality test (Shapiro-Wilk test), multicoleniarity test (variance inflating 
factor;VIF), homoskedasticity test (Glejser test and Spearman Rho test), and non-autocorrelation (Durbin-Watson).

\section{RESULTS AND DISCUSSION}

\section{Multiple feeding systems on palm oil mill effluent properties}

The POME processed with a multiple feeding system in WWTP has the biochemical content relatively identical to the results reported by other researchers (Tong, 2011; Mahajoeno, 2008; Wu et al., 2010; Sarono, 2014); (Table 1), the difference in BOD levels in this study was lower due to the quality of FFB raw materials, oil palm harvest season, and laboratory test methods. Both COD and BOD variables are references in determining the organic matter content of POME, so that estimates of the amount and rate of methane emissions can be determined (IPCC, 2006).

All test results variables do not meet BMLC (Regulation of Environment Minister 05/2014), but meet BMLA (Decree of Environment Minister 29/2003), either raw POME from fat-pit from the factory or WWTP output (effluent or AP3 outlet), which utilizes wastewater for land application (LA). This fact explains that POME with high levels of organic matter is a source of environmental pollution, and required management and improvement of technology for its processing.

The biochemical levels of POME in Table 1 with COD content of almost $45,000 \mathrm{mg} / \mathrm{L}$ - apart from being a source of pollution - also had the potential to produce biogas containing methane gas as an energy source (Sarono, 2014). The value of organic matter content on POME, as indicated by COD content, has a conversion factor with methane gas. Theoretically (stoichiometry) the degradation process of organic matter every $1 \mathrm{~kg}$ of COD can be produced $0.35 \mathrm{~m}^{3}$ or $0.25 \mathrm{~kg} \mathrm{CH}_{4}$ under STP conditions (standard temperature and pressure; $0^{\circ} \mathrm{C}$ and $1 \mathrm{~atm}$ ); (IPCC, 2006), although from many fieldscale studies of value had rarely been achieved (Yacob et al., 2006; Hasanudin et al., 2006; Park and Craggs, 2007; Paredes et al., 2015).

This wastewater treatment system, with simple POME processing techniques, has shorter HRT (hydraulic retention times); $(<35$ days on AP3), wide area of ponds and fewer ponds (7 ponds and area $<1.4$ hectares); (Figure 1). WWTP with this system is able to reduce the POME variable COD, BOD, TSS, TS, VS, N-total, and oil and grease $81.56 ; 86.56 ; 59.09 ; 64.25 ; 68.89$; $17.47 ; 88.59 \%$, and increased $\mathrm{pH} 59.38 \%$ respectively. The mean value of raw POME variable COD was 44,917 mg/L and AP3 POME outlet was $8,283 \mathrm{mg} / \mathrm{L}$. This indicated that the WWTP system was capable of removing COD in the amount of $36,633 \mathrm{mg} / \mathrm{L}(81.56 \%)$; (Table 2). The use of COD variables was suitable for estimating methane emissions in POME and other types of wastewater (IPCC, 2006; Yacob et al., 2006; Basri et al., 2010). The removing of COD variables in anaerobic ponds (AP1 to AP3) was able to reduce $21,050 \mathrm{mg} / \mathrm{L}(46.86 \%)$, and final processing wastewater with a value of COD 8.283 $\mathrm{mg} / \mathrm{L}(18.44 \%)$ for the use of land applications and sources of nutrients for plant.

Table 1. Characteristics of POME from the waste pond tested

\begin{tabular}{|cccccccc|}
\hline \multirow{2}{*}{ Variable $^{\mathrm{a}}$} & \multirow{2}{*}{ Unit } & \multicolumn{2}{c}{ Inlet WWTP (Raw POME) } & \multicolumn{2}{c|}{ Outlet WWTP (AP3) } & \multicolumn{2}{c|}{ Removed } \\
\cline { 3 - 8 } & & Mean & Interval & Mean & Interval & Value & $\%$ \\
\hline COD & $\mathrm{mg} / \mathrm{L}$ & $44,917 \pm 11,889$ & $33,500-66,000$ & $8,283 \pm 4,846$ & $2,200-16,000$ & 36,633 & 81.56 \\
BOD & $\mathrm{mg} / \mathrm{L}$ & $9,567 \pm 2,551$ & $6,060-11,961$ & $1,285 \pm 203$ & $1,007-1,546$ & 8,281 & 86.56 \\
TSS & $\mathrm{mg} / \mathrm{L}$ & $52,610 \pm 20,390$ & $31,530-90,350$ & $21,522 \pm 9,664$ & $11,850-31,720$ & 31,088 & 59.09 \\
TS & $\mathrm{mg} / \mathrm{L}$ & $54,053 \pm 13,912$ & $37,920-71,620$ & $19,327 \pm 5,116$ & $13,720-27,220$ & 34,727 & 64.25 \\
VS & $\mathrm{mg} / \mathrm{L}$ & $46,813 \pm 13,835$ & $29,840-65,640$ & $14,565 \pm 5,352$ & $7,980-20,940$ & 32,248 & 68.89 \\
N-total & $\mathrm{mg} / \mathrm{L}$ & $1,789 \pm 719$ & $1,234-3,046$ & $1,476 \pm 357$ & $1,083-1,997$ & 313 & 17.47 \\
Oil and grease & $\mathrm{mg} / \mathrm{L}$ & $18,083 \pm 10,456$ & $5,570-32,860$ & $2,063 \pm 1,492$ & $780-4200$ & 16,020 & 88.59 \\
pH & -- & $4.59 \pm 0.08$ & $4.46-4.69$ & $7.31 \pm 0.11$ & $7.22-7.50$ & -2.72 & $-59.38^{\mathrm{b}}$ \\
Eh & $\mathrm{mV}$ & $157 \pm 7$ & $147-169$ & $(-20) \pm 7$ & $(-33)-(-14)$ & 177 & $112.61^{\mathrm{c}}$ \\
Suhu & ${ }^{\circ} \mathrm{C}$ & $67.5 \pm 3.0$ & $62.4-70.4$ & $33.4 \pm 1.6$ & $32.4-36.8$ & 34 & 50.51 \\
\hline
\end{tabular}

${ }^{\text {a }} \mathrm{TSS}=$ total suspended solid; $\mathrm{TS}=$ total solid; VS=volatil solid; $\mathrm{Eh}=$ redox potential.

${ }^{\mathrm{b}}$ Negative percentage means an increase.

${ }^{\mathrm{c}}$ Eh value percentage is from positive $(157 \mathrm{mV}$; low reduction) to negative $(-20 \mathrm{mV}$; moderate reduction), so $>100 \%$. 
Table 2. Decreasing COD variables in WWTP with multiple feeding system

\begin{tabular}{|c|c|c|c|c|c|c|}
\hline \multirow{2}{*}{ Characteristics of COD variables } & \multicolumn{2}{|c|}{ Deoiling-Cooling pond } & \multicolumn{4}{|c|}{ Anaerobic pond } \\
\hline & IN-DP & OUT-DP & IN-AP2 & OUT-AP2 & IN-AP3 & OUT-AP3 \\
\hline $\mathrm{COD}(\mathrm{mg} / \mathrm{L})$ & 44,917 & 41,000 & 29,333 & 12,967 & 16,963 & 8,283 \\
\hline Decreasing of COD (mg/L); (\%) & $0(0.00)$ & $3,917(8.72)$ & $15,583(34.69)$ & $31,950(71.13)$ & $27,953(62.23)$ & $36,633(81.56)$ \\
\hline \multicolumn{7}{|l|}{ Decreasing of COD and final outlet: } \\
\hline a. Inlet deoiling pond to Inlet AP2 (mg/L); (\%) & \multicolumn{3}{|c|}{$15,583(34.69)$} & & & \\
\hline b. Inlet AP2 to outlet AP3 (mg/L); (\%) & & & \multicolumn{4}{|c|}{$21,050(46.86)$} \\
\hline c. Outlet final IPAL (Outlet); (mg/L); (\%) & \multicolumn{6}{|c|}{$8,283(18.44)$} \\
\hline
\end{tabular}

Decreasing the COD variable was $81.56 \%$ higher than obtained by Yacob et al., 2005 (80.7\%), but smaller than in Yacob et al., 2006 $(97.8 \%)$ based on field-scale research results; smaller than the results of Faisal and Unno, 2001, Najafpour et al., 2006, and Sarono, 2014, amounting to $95.3,97$ and $86.86 \%$ respectively, in laboratory-scale research. The decrease in COD variable occured in anaerobic ponds and non-anerobic ponds (deoiling-cooling ponds) was 46.86 and $34.60 \%$ (or 21,050 and $15,583 \mathrm{mg}$ / L), respectively (Table 2), which showed that the AP performance was still not optimal, due to siltation of ponds by sludge (digestate). As a result, the process of reforming organic matter by micro-organisms became shorter and the process of forming biogas (methane) was not completed.

The negative Eh values indicated a moderatestrong reduction reaction, in the formation of methane (metanogenesis), as in the measurement results of the average variable value of Eh- $20 \mathrm{mV}$ (Table 1) and $-26 \mathrm{mV}$ (moderate reduction) at AP3 outlets and AP2 outlets, respectively. Meanwhile, positive Eh (low reduction) occurred on AP3 and AP2 inlets, reaching 27 and $154 \mathrm{mV}$, respectively. Medium-strong reduction with negative values is a condition for the formation of methane gas. According to Drapcho et al. (2008), anaerobic conditions must be maintained for the production of methane gas in the Eh-300 mV for the growth of methanogenic bacteria.

\section{The rate of methane emissions}

Measuring the rate of methane emissions by using chambers and the TGS2611 sensor-based $\mathrm{CH}_{4}$-meter system in anaerobic ponds of multiple feeding system palm oil mills has not been widely reported. Determination of the sampling points location was based on consideration of microbial activity, high, low and medium rate of biogas (methane) emissions and previous research, namely inlet, middle and outlets pond (Yacob et al., 2006; Park and Craggs, 2007; Mahajoeno, 2008; Paredes et al., 2015). The TGS2611 and SHT11 sensors mounted on the chamber were capable of detecting and presenting data on methane gas concentrations and chamber temperatures according to the manufacturer's technical data (Figaro, 2012). Some data with methane gas values $>1.5 \%$ were still able to read well.

Methane emissions in combined anaerobic ponds (AP2-AP1) and AP3 reached 43,704 and $35,321 \mathrm{mg} / \mathrm{m}^{2} /$ day, respectively, with a total of $405.358 \mathrm{~kg} / 9,275 \mathrm{~m}^{2} /$ day at AP2-AP1 and 61.812 $\mathrm{kg} / 1,750 \mathrm{~m}^{2}$ /day on AP3 (Table 3). The highest value of methane emissions was at the sampling point near the inlet and the lowest was at the location of sampling the middle of the pond both on AP2-AP1 and AP3. The high value of methane emissions was caused by the location of the inlet, i.e. the point of entry for the wastewater with the highest organic matter content compared to the other two sampling points. At this location, the rate of biogas production (methane) was highest, but the lowest methane content was lowest (Yacob et al., 2006; Mahajoeno, 2008).

The value of methane emissions was near the highest inlet in the presence of gas bubbles, then increased near the outlet, and the lowest in the middle of the pond. The micro-organism activity was seen to increase along with surface temperatures leading to daylight (Park and Craggs, 2007), but when the rainfall occurred, the emissions decreased, and a scum/solid organic matter was formed which could be seen on the ponds. These conditions could be seen on AP2 and AP3; however, it was less on AP1. This was because the AP1 pond was just an additional water reservoir, with the AP1 pond outlet returning to AP2 (Figure 3).

In this study, the methane emissions were still lower than the ones obtained by previous researchers. Yacob et al., 2006 produced methane 
Table 3. Methane emissions in anaerobic ponds

\begin{tabular}{|c|c|c|c|c|}
\hline \multirow{2}{*}{ Sampling location } & \multicolumn{2}{|c|}{ Anaerobic Pond AP2-AP1 } & \multicolumn{2}{c|}{ Anaerobic Pond AP3 } \\
\cline { 2 - 5 } & Emission $\mathrm{CH}_{4}\left(\mathrm{mg} / \mathrm{m}^{2} /\right.$ day $)$ & $\mathrm{n}$ & Emission $\mathrm{CH}_{4}\left(\mathrm{mg} / \mathrm{m}^{2} /\right.$ day $)$ & $\mathrm{n}$ \\
\hline Inlet & $97,534 \pm 45,223$ & 3 & $49,715 \pm 1,963$ & 3 \\
\hline Middle & $11,631 \pm 11,546$ & 3 & $27,499 \pm 18,461$ & 3 \\
\hline Outlet & $21,948 \pm 15,546$ & 3 & $28,750 \pm 4,978$ & \\
\hline Mean & $43,704 \pm 38,295$ & & $35,321 \pm 12,481$ & 3 \\
\hline
\end{tabular}

Remark: Methane emissions AP2-AP1 $405.358 \mathrm{~kg} /$ day with an area of $9,275 \mathrm{~m}^{2}$ and AP3 $61.812 \mathrm{~kg} /$ day with an area of $1,750 \mathrm{~m}^{2}$, a total of $467.170 \mathrm{~kg} / \mathrm{hr}\left(11,025 \mathrm{~m}^{2}\right)$.

emissions of $1,043.1 \mathrm{~kg} /$ pond $\left(1,373 \mathrm{~m}^{2}\right) /$ day and Mahajoeno, 2008 reported 1,935.6 kg/pond $\left(10,800 \mathrm{~m}^{2}\right) /$ day, or each equivalent to 759,723 and $179,222 \mathrm{mg} / \mathrm{m}^{2} / \mathrm{day}$, while this research is 43,704 and $35,321 \mathrm{mg} / \mathrm{m}^{2} /$ day for AP2-AP1 and AP3, respectively. This is due to the condition and performance of the AP which is not optimal in the degradation of organic matter in POME, owing to siltation of ponds, which results in shorter HRT, so that the performance of microorganisms in degradation of organic matter is not optimal. HRT that is too short causes the process of overhauling organic matter to be incomplete or pushes bacteria out of the digester (Rahayu et al., 2015).

The methane emissions on AP2-AP1 were higher than AP3, this is highly related to HRT and the load of organic matter (OLR) of waste entering the AP2-AP1 was higher in the organic content. In the multiple feeding system, AP3 received the same wastewater and even higher volumes (AP3 - 60\% volume and AP2-AP1 - 40\% when the study was conducted), but at the same time, AP3 received flow from AP2 with wastewater degraded, while AP2 was directly fed from the cooling pond with higher levels of organic matter.
Another finding obtained from this study was that methane emissions on AP were strongly influenced by the presence of rain that increased the liquid volume and reduced the temperature of anaerobic ponds, this phenomenon was seen in AP2-AP1 and AP3 (Figure 4). In AP2-AP1 on day 3 , there was a volume of $85 \mathrm{~mm} / 12$ hours (14.45-16.00) of rain, causing the rate of methane emissions to decline by $22.78 \mathrm{~g} / \mathrm{m}^{2} /$ day, but on the contrary when the sun was clear without rain on day 1 , the highest emission rate was obtained $\left(69.58 \mathrm{~g} / \mathrm{m}^{2} /\right.$ day). Likewise, in the AP3, the first day of rainfall with a volume of $16 \mathrm{~mm} / 12$ hours (15.35-16.20) caused the lowest methane emission rate of $30.08 \mathrm{~g} / \mathrm{m}^{2} /$ day and day 2 with bright sun resulted in the highest rate of methane emissions $\left(44.78 \mathrm{~g} / \mathrm{m}^{2} /\right.$ day $)$.

\section{Conversion coefficient of methane emissions}

By plotting the data between COD removed and the rate of production of methane in the APAP1 and AP3 anaerobic ponds, the conversion coefficient or conversion factor was obtained. In the AP2-AP1 and AP3 ponds based on this study,



Figure 4. Effect of rain on the rate of methane emissions 

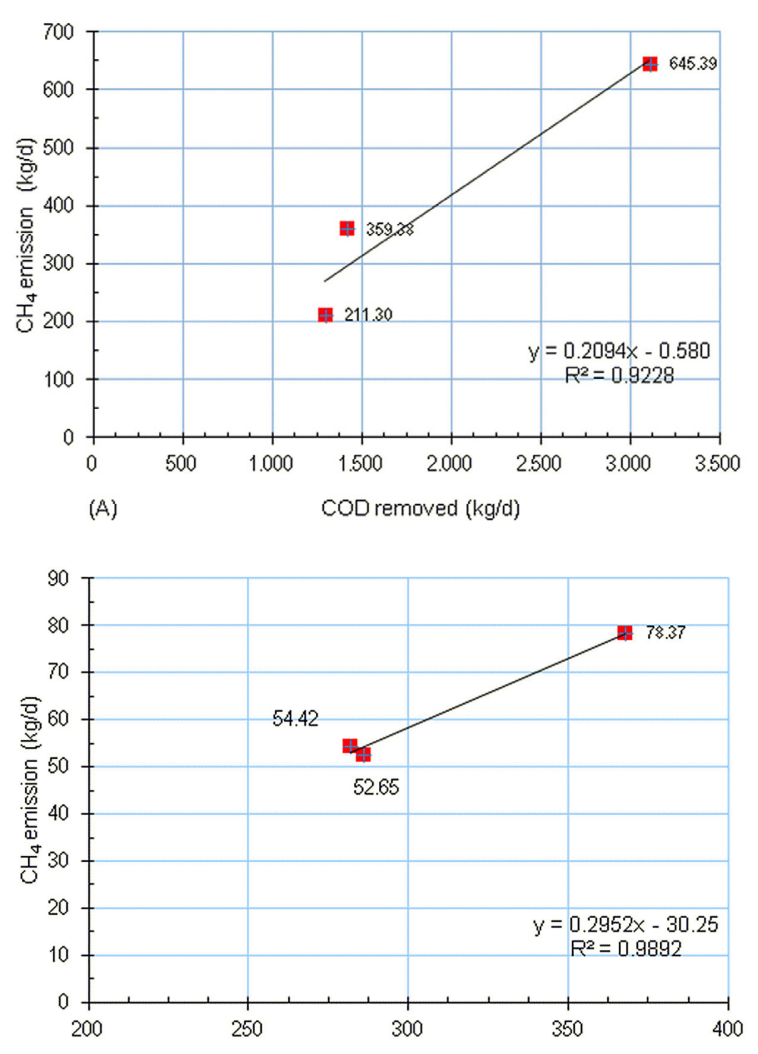

(B)

COD removed $(\mathrm{kg} / \mathrm{d})$

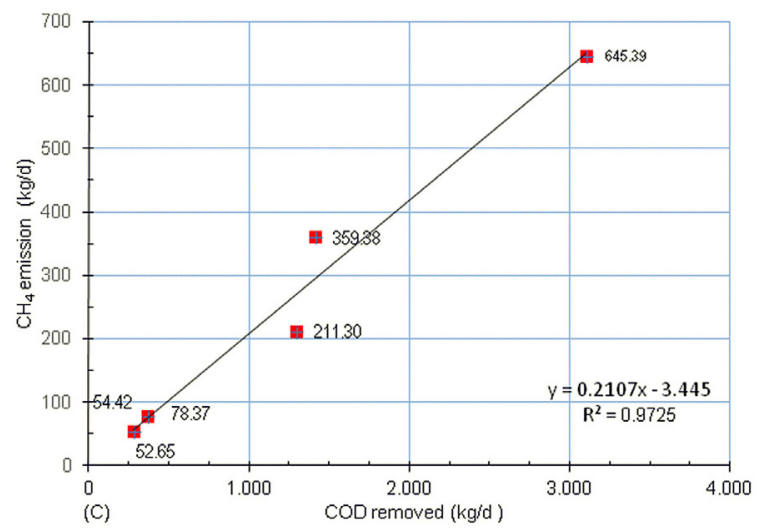

Figure 5. Relationship between methane emissions and COD removed: A) AP2-AP1 pond,

B) AP3 pond, C) combined pond AP-AP1 and AP3

0.2094 and $0.2952 \mathrm{~kg} \mathrm{CH}_{4} / \mathrm{kg} \mathrm{COD}$ removal was obtained, respectively, while using all data, $0.2107 \mathrm{~kg} \mathrm{CH}_{4} / \mathrm{kg}$ COD was removed (Figure 5). This value was based on linear regression with a significant coefficient of determination $\left(\mathrm{R}^{2}\right)$, $0.9228 ; 0.9892$ and 0.9725 , respectively. The high $\mathrm{R}^{2}$ value stated that the independent variable (COD removed) was able to explain the dependent variable $\left(\mathrm{CH}_{4}\right.$ emissions) significantly, while the rest $\left(1-\mathrm{R}^{2}\right)$ was the influence of other variables. Compared to the research of Yacob et al., 2006, the results of this study had better distribution of data and were very close to linear lines, with high $\mathrm{R}^{2}(>0.92)$.

The conversion coefficient value obtained in this study was $0.2107 \mathrm{~kg} \mathrm{CH} / \mathrm{kg}$ COD removed, smaller than Yacob et al., 2006 (0.238) in the WWTP anaerobic pond of palm oil mills in Malaysia, but higher than in the research of Hasanudin et al., 2006 (equivalent to 0.105) in the AP tapioca factory in Lampung, Indonesia. This difference was very dependent on harvesting and factory activities (Yacob et al., 2006), environmental factors, and wastewater treatment systems. From the previous research mentioned above and the results of this study. the obtained conversion coefficient was below the theoretical value (stoichiometry) $0.25 \mathrm{~kg} \mathrm{CH}_{4} / \mathrm{kg} \mathrm{COD}$ removed. This conversion coefficient could be used in the rapid estimation of methane emissions in Indonesian palm oil mills, especially for conversion to energy sources and control of greenhouse gases in oil palm agro industry.

From the anaerobic ponds of all WWTPs, the average AP2-AP1 COD inlets and AP3 outlets (IPAL outlets) were 29,333 and $8,283 \mathrm{mg} / \mathrm{L}$, respectively, so the COD removed was distributed across all anaerobic ponds of 21,050 mg/L (21.05 $\left.\mathrm{kg} / \mathrm{m}^{3}\right)$. Using the conversion coefficient, COD removed and the number of production POME, $104,179 \mathrm{~m}^{3}$ of methane gas would be emitted in 2018 throughout the anaerobic ponds of 462 tons.

\section{Relation of methane emissions and wastewater characteristic}

The multiple linear regression equation was built to determine the relationship of the biochemical variables of wastewater with methane emissions. The resulting regression equations fulfilled the regression assumptions. Methane emissions were influenced by the levels of COD, VS, oil and grease, N-total, in the form of a logarithmic linear regression equation, as follows:

$$
\begin{gathered}
\ln \left(\mathrm{CH}_{4}\right)=3.139+0.245 . \ln (\mathrm{COD}-\mathrm{R})+ \\
+0.620 . \ln (\mathrm{VS}-\mathrm{R})-0.012 .(\mathrm{COD} / \mathrm{Ntot}-\mathrm{R})+ \\
+0.002 .(\mathrm{ML}-\mathrm{R} / \mathrm{Ntot}-\mathrm{R}) ;\left(\mathrm{R}^{2}=0.585\right)
\end{gathered}
$$

Where: $\mathrm{CH}_{4}$ is emissions of methane emission rate $\left(\mathrm{mg} / \mathrm{m}^{2} /\right.$ day), COD- $\mathrm{R}$ is chemical oxygen demand, VS-R is volatile solid, Ntot- $\mathrm{R}$ is total nitrogen, and ML-R is oil and grease removed $(\mathrm{mg} / \mathrm{L})$.

Regression equation had fulfilled the residual normality test (Shapiro-Wilk test; significance $>0.05$ ), multicollinearity test (variance 
inflating factor (VIF) <10), homoskedasticity test (Glejser test and Spearman Rho test; significance $>0.05$ ), and non-autocorrelation (DurbinWatson). However, the ANOVA results of the regression equation were not significant with the coefficient of determination $\left(\mathrm{R}^{2}\right) 0.585$. On the basis of the $\mathrm{R}^{2}$ value, all predictors of VS$\mathrm{R}, \mathrm{COD}-\mathrm{R}, \mathrm{N}$-total, and oil and grease together were able to determine the value of methane emissions by 0.585 , and the remaining 0.415 were influenced by other factors. $\mathrm{R}^{2}$ also explains how reliably the model formed is able to explain the condition of the independent variables measured in the field and the use of appropriate regression methods.

Logarithmic data transformation aims at normalizing data so that it can meet regression assumptions. Natural logarithms (ln) were for $\mathrm{CH}_{4}, \mathrm{COD}-\mathrm{R}$, and VS-R emission variables, and transformation ratios in COD-R and ML-R with $\mathrm{N}$-total. The significance value of the model obtained was strongly influenced by the amount of data used in building the regression model, even though the value of $\mathrm{R}^{2}$ was able to show the effect of COD, VS, ML and N-total variables simultaneously on methane gas emissions in organic change activities in anaerobic ponds.

VS variable was related to volatility and fixed solid. The anaerobic microbial activity in the decomposition of organic matter produces biogas (methane), highly determined from COD variables (IPCC, 2006) and solid volatile (VS); (Drapcho et al., 2008; Park and Craggs, 2007). Furthermore, Drapcho et al. (2008), reported that every $\mathrm{kg}$ of VS was degraded in the anaerobic process of urban domestic wastewater would result in $0.7 \mathrm{~m}^{3}$ $\mathrm{CH}_{4}$. Besides using COD variables, based on this study, the use of VS variables was possible for a conversion coefficient $\left(\mathrm{kg} \mathrm{CH}_{4} / \mathrm{kg} \mathrm{VS}\right)$. However, further studies need to be conducted.

The value of $\mathrm{C} / \mathrm{N}$ ratio also affected the microbial productivity in methane formation. The $\mathrm{C} / \mathrm{N}$ ratio could be approached with total $\mathrm{COD} / \mathrm{N}$-total and $\mathrm{ML} / \mathrm{N}$-total ratios which were linearly related to methane gas production. This is a new finding, but this needs further study. The change in organic content in the anaerobic process requires a balance of COD:N:P ratio of 800:5:1 in the wine industry wastewater (Moletta, 2005). COD:N:P ratio of 333:4:1 for pear waste and 500:9:1 from melons, but the anaerobic performance of the digester is adequate at a ratio of 300:5:1 (Drapcho et al., 2008).
The COD variable showed the amount of chemical oxygen demand in reforming POME organic matter, which reflected the amount of carbon (C-organic) contained in the substrate of palm oil waste water. The COD/N-total ratio could be directly obtained by mathematical comparison of COD and Ntotal, which has become a mandatory test variable in the operational compliance of WWTPs in oil palm plant. The above-mentioned facts indicate that the variables COD and / or VS were strong enough to be used in determining methane gas emissions quickly.

The process of anaerobically changing organic matter required nutrients to grow and multiply. Too low substrating with a $\mathrm{C} / \mathrm{N}$ ratio would result in an increase in ammonia levels which could inhibit the methane production. Conversely, if the $\mathrm{C} / \mathrm{N}$ ratio is too high, indicating a lack of nitrogen on the substrate, this has a negative impact on the formation of proteins needed by microbes to grow. Therefore, it was necessary to balance the $\mathrm{C} / \mathrm{N}$ ratio so that methane gas production was more optimal (Deublein and Steinhausher, 2008). He further said that the optimal $\mathrm{C} / \mathrm{N}$ was $16: 1-25: 1$; and 20:1 - 30:1, according to Stafford et al. (1980).

The oil and grease content could be seen from the $\mathrm{ML} / \mathrm{N}$-total ratio, grease is a very slowly hydrolyzed complex organic compound. Grease is a limiting factor for the rate of hydrolysis, in the anaerobic decomposition of organic matter. This compound had excessive amounts of long chain fatty acids and could inhibit the microbial work in the formation of biogas (Adrianto et al., 2001).

\section{CONCLUSION}

Fresh POME (influent) had variable levels of COD, BOD, TSS, TS, VS, N-total, oil and grease, and $\mathrm{pH} 44,917 ; 9,567 ; 52,610 ; 54,053$; 46,$813 ; 1,789 ; 18,083 \mathrm{mg} / \mathrm{L}$ and 4.59 , respectively. Wastewater treatment with a multiple feeding system was able to reduce the above-mentioned variables in a row $81.56 ; 86.56 ; 59.09 ; 64.25$; $68.89 ; 17.47 ; 88.59 \%$, respectively, and increased $\mathrm{pH}$ by $59.38 \%$. Methane gas emissions in combined anaerobic ponds (AP2-AP1) and AP3 were 43,704 and $35,321 \mathrm{mg} / \mathrm{m}^{2} /$ day, respectively, and a total of 405.358 and $61.812 \mathrm{~kg}$ /day were obtained in AP2-AP1 $\left(9,275 \mathrm{~m}^{2}\right)$ and AP3 $\left(1,750 \mathrm{~m}^{2}\right)$, respectively. The correlation between the methane gas emissions with COD removed was obtained, as the conversion coefficient of $0.2107 \mathrm{~kg} \mathrm{CH}_{4} / \mathrm{kg}$ 
COD removed. These values were based on linear regression with the coefficient of determination $\left(\mathrm{R}^{2}\right)$ equal to 0.9725 . The average value of COD in the whole anaerobic pond was $21,050 \mathrm{mg} / \mathrm{L}$, using the conversion coefficient obtained, and the production of POME in 2018 equalled 104,179 $\mathrm{m}^{3}$, which had emitted 462 tons of methane gas . Variable wastewater COD, VS, N-total, oil and grease, together had an effect on methane emissions in anaerobic ponds, in the form of logarithmic linear regression with $\mathrm{R}^{2} 0.585$ and had met the regression assumptions.

\section{Acknowledgement}

The author would like to thank the management of PT SPOI for permission and cooperation during field research. The author also thanked Mr. Iwan Sugriwan and Rahmat in preparing the $\mathrm{CH}_{4}$-meter system; Mr. Widodo, Dian Novriady, Syafriansyah, Adi Kurniadi, Ali Ma'ruf Saputra for their support in equipment installation, data analysis, and field data collection.

\section{REFERENCES}

1. Adrianto A., Setiadi T., Syafilla M., Liang, O.B. 2001. Kinetics study of hydrolysis reactions of organic complex compounds in the anaerobic biodegradation process. J. Biosains, 1(10) (in Indonesian).

2. APHA. 1998. Standard methods for the examination of water and wastewater. American Public Health Association/American Water Works Association/Water Environment Federation, Washington DC, USA.

3. Arif C., Setiawan B.I., Widodo S., Rudiyanto, Hasanah, Mizoguchi M. 2015. Development of artificial neural network models to estimate greenhouse gas emissions from paddy fields with various water regimes. Jurnal Irigasi, 10(1), 1-10 (in Indonesian).

4. Basri M.F., Yacob S., Hassan M.A., Shirai Y. 2010. Improved biogas production from palm oil mill effluent by a scaled-down anaerobic treatment process. World J Microbiol Biotechnol, 2010(26), : 505-514. https://DOI 10.1007/s11274-009-0197-X

5. Buana L., Kurniawan A., and Siahaan D. 2004. Profile of the Indonesian palm oil industry. In Kurniawan A., Dja'far D., Siahaan L., Buana and T. Wahyono (Editor). Economic overview of the palm oil industry. Palm Oil Research Center. Medan (in Indonesian).

6. Deublein D., and Steinhauser A. 2008. Biogas from waste and renewable resource. Wiley-VCH
Verlag GmbH \& Co. KgaA. Weinheim.

7. Directorate General of Plantation. 2016. Indonesian plantation statistics 2015-2017 Oil Palm. Directorate General of Plantation, Ministry of Agriculture. Jakarta (in Indonesian).

8. Djamhur A.E.S. 2015. The Motivation of the United States to Block Indonesian CPO (Crude Palm Oil) from Entering the 2012 EEC List (Environmental Good List), APEC Tahun 2012. JOM FISIP, 2(2), 1-12 (in Indonesian).

9. Drapcho C.M., Nhuan N.P., Walker T.H. 2008. Biofuels engineering proces technology. United States: The McGraw-Hill Companies Inc.

10. Eugster W., and Kling G.W. 2012. Performance of a low-cost methane sensor for ambient concentration measurements in preliminary studies. Atmos. Meas. Tech, 2012(5), 1925-1934.

11. Faisal M. and Unno H. 2001. Kinetic analysis of palm oil mill wastewater treatment by a modified anaerobic baffled reactor. Biochem. Eng. J., 9, 25-31.

12. Figaro. 2012. Technical information for methane gas sensors TGS2611. Figaro Engineering Inc. Osaka Jepang.

13. GAPKI. 2017. Reflections on the 2016 palm oil industry \& prospects 2017. Press releases of the Indonesian Palm Oil Entrepreneurs Association (GAPKI) reflect the 2016 palm oil industry and prospects for 2017 (in Indonesian).

14. Harmita. 2004. Instructions for implementing method validation and calculations. Pharmaceutical Science Magazine, 1(3), 117-135 (in Indonesian).

15. IAEA. 1992. Manual on measurement of methane and nitrous oxide emissions from agriculture. A joint Undertaking by The Food and Agriculture Organization of The United Nations and The International Atomic Energy Agency, Vienna, Austria.

16. IPCC. 2006. Guidelines for national greenhouse gas inventories; Vol. 5: Waste, Chapter 6: Wastewater Treatment and Discharge. Paris- Francia.

17. Khalil M.A.K., Rasmussen R.A., Wang M.X., and Ren L. 1991. Methane emission from rice fields in China. Environment Science Technology, 25, 979-981.

18. Lam M.K., and Lee K.T. 2011. Renewable and sustainable bioenergies production from palm oil mill effluent (pome): win-win strategies toward better environmental protection. Biotechnology Advances Journal, 29(2011), 124-141.

19. Lantin R.S., Aduna J.B., and Javeliana A.M. 1995. Methane measurements in rice fields. International Rice Research Institute. Los Banos, Manila, Philippines.

20. Lorke A., Bodmer P., Noss C., Alshboul Z., Koschorreck M., Somlai-Haase C., Bastviken D., 
Flury S., McGinnis D.F., Maeck A., Müller D., and Premke K. 2015. Technical note: Drifting versus anchored flux chambers for measuring greenhouse gas emissions from running waters. Biogeosciences, 12, 7013-7024. www.biogeosciences. net/12/7013/2015/doi:10.5194/bg-12-7013-2015

21. Mahajoeno, E., 2008. Development of renewable energy from palm oil mill effluent. (Dissertation) Study Program of Natural and Environmental Resources Management, Postgraduate School of Bogor Agricultural University (in Indonesian).

22. Moletta R. 2005. Winery and distillery wastewater treatment by anaerobic digestion. Water Sci Technol., 51(1), 137-144.

23. Morad N., Choo S.S., Ho, Y.C. 2008. Simplified Life Cycle Assessment of Crude Palm Oil - A Case Study at a Palm Oil Mill. International Conference on Environmental Research and Technology (ICERT 2008).

24. Najafpour G.D., Zinatizadeh A.A.L., Mohamed A.R., Hasnain I.M., and Nasrollahzadeh H. 2006. High rate anaerobic digestion of palm oil mill effluent in an upflow anaerobic sludge fixed film bioreactor. Process Biochemistry, 41, 370-379.

25. Paredes M.G., Güerecaa L.P., Molinab L.T., and Noyolaa A. 2015. Methane emissions from stabilization ponds for municipal wastewater treatment in Mexico. Journal of Integrative Environmental Sciences, 12(SI), 139 - 153.

26. Park J.B.K. and Craggs R.J. 2007. Biogas production from anaerobic waste stabilisation ponds treating dairy and piggery wastewater in New Zealand. Water Science and Technology, 55(11), 257-264.

27. Porteous A. 1998. Energy from waste: a wholly acceptable waste-management solution. Applied Energy, 58, 177-208.

28. Rahayu U.S., Karsiwulan D., Yuwono H., and Paramita V. 2015. POME to Biogas Conversion Handbook: Project Development in Indonesia. Winrock International. Jakarta. http://winrock-indo.org/ 4732.html (in Indonesian).

29. Sarono 2014. Strategy to reduce greenhouse gases through the conversion of palm oil mill effluent into electricity (case study in Lampung Province). (Dissertation) Study Program of Agricultural Industry Technology, Postgraduate School of Bogor Agricultural University (in Indonesian).

30. Senserion. 2011. Datasheet SHT1x (SHT10, SHT11, SHT15) Humidity and Temperature Sensor IC, Version 5 - December 2011. www.sensirion.com

31. Silva J.P., Lasso A., Lubberding H.J., Pena M.R., and Gijzen H.J. 2015. Biases in greenhouse gases static chambers measurements in stabilization ponds: Comparison of flux estimation using linear and non-linear models. Atmospheric Environment, 109(2015), 130-138.

32. Silva J.P. 2016. Greenhouse gas emissions from a pilot-scale small decentra lized sewage treatment : anaerobic filter + constructed wetland. Ingeniería Y Competitividad, 18(2), 101 - 112.

33. Stafford D.A., Hawkes D.L., and Horton R. 1980. Methane production from waste organic matter. CRC Press, Inc., Boca Raton, Florida.

34. Sugriwan I., Rachmattulah A., Soesanto O., and Harnawan A.A. 2015. Design and fabrication of methane $\left(\mathrm{CH}_{4}\right)$ gas measuring devices on peatlands using TGS2611 sensors ATMega8535 based. Journal of Neutrino, 8(1), 11-20 (in Indonesian).

35. Sugriwan I., and Soesanto O. 2017. Development of TGS2611 methane sensor and SHT11 humidity and temperature sensor for measuring greenhouse gas on peatlands in South Kalimantan, Indonesia. International Conference on Physical Instrumentation and Advanced Materials IOP Publishing. IOP Conf. Series: Journal of Physics: Conf. Series 853.

36. Tong S.L. 2011. Recent developments on palm oil mill residues biogas recovery and utilisation. International Conference and Exhibition of Palm Oil, Jakarta, 11-13, May 2011.

37. Wicke B., Veronika D., Martin J., and Andre F. 2008. Different palm oil production systems for energy purposes and their green house gas implications. Biomass and Bioenergy, 32, 1332-1337.

38. Wu T.Y., Abdul W.M., Jamaliah M.J., and Nurina A. 2010. Pollution control technologies for the treatment of palm oil mill effluent (POME) Through end-of-Pipe Processes. Journal of Environ. Management, 9, 1467-1490.

39. Yacob S., Hassan M.A., Shirai Y., Wakisaka M., and Subash S. 2005. Baseline study of methane emission from open digesting tanks of palm oil mill effluent treatment. Chemosphere, 59(11), 1575-1581. https://doi.org /10.1016/j.chemosphere.2004.11.040

40. Yacob S., Hassan M.A., Shirai Y., Wakisaka, M. and Subash S. 2006. Baseline study of methane emission from anaerobic ponds of palm oil mill effluent treatment. Science of the Total Environment, 366(2006), 187-196.

41. Yuliasari R., Darnoko, Wulfred K., and Gindulis W. 2001. Processing of palm oil mill effluent with downstream type fixed bed anaerobic unggun reactors. PPKS Newsletter, 9, 75-81 (in Indonesian). 